\title{
PERKEMBANGAN FENOMENOLOGI PADA REALITAS SOSIAL MASYARAKAT DALAM PANDANGAN EDMUND HUSSERL
}

\author{
Supriadi* \\ Stikosa-AWS, Surabaya, INDONESIA \\ * Penulis korespondensi, email: r4y4prian@yahoo.com
}

\begin{abstract}
ABSTRAK
Paradigma utama sosiologi fakta sosial, definisi sosial dan perilaku sosial sesungguhnya mencoba menjelaskan tarik ulur individu atau dikenal dengan aktor dan masyarakat, termasuk struktur di dalamnya. Persoalannya adalah apakah individu yang mempengaruhi struktur ataukah struktur mendominasi individu, sehingga tidak memiliki pilihan lain untuk bertindak. Ada pendekatan-pendekatan lain yang bersifat radikal dalam arti menolak pangandaian ortodoksi 'fungsionalisme struktural' yang menjadi mainstrem, cap yang diberikan kepada sintesis Talcott Parson atas organisme Durkheim dan Teori Tindakan Sosial Weber yang mendiminasi teori sosial pasca Perang Dunia Kedua, yaitu fenomenologi. Dunia-kehidupan dalam pengertian Husserl kurang lebihnya mengandung arti bahwa, dunia sebagaimana manusia menghayati dalam spontanitasnya, sebagai basis tindakan komunikasi antar subjek. Dunia-kehidupan ini adalah unsur-unsur sehari-hari yang membentuk kenyataan kita, yakni unsur dunia sehari-hari yang kita libati dan hidupi sebelum kita menteorikannya atau menrefleksikannya secara filosofis. Fenomenologi melihat komunikasi sebagai sebuah proses membagi pengalaman personal melalui dialog atau percakapan. Fenomenologi adalah disiplin ilmu yang berbeda dari namun masih memilki hubungan dengan disiplin dalam bidang filsafat, seperti ontology, epistomologi, logic dan ethics. Yang membedakan pada penemuan pengetahuan dalam fenomenologi ialah mengesampingkan sementara segala teori, pendapat dan pandangan yang telah diketahui sebelumnya oleh setiap orang, dengan tujuan agar dapat menangkap hakikat yang murni. Sebagai tolok ukurnya ialah kebenaran intersubjektif, kebenaran pengetahuan jika melakukan eksplorasi makna noumenon di balik yang phenomenon menuju metateori dan metasains. Langkah-langkah metode yang dipakai ialah (1). Reduksi fenomenologis, (2). Reduksi Eidetik, (3). Reduksi transendental. Artikel ini akan mendeskripsikan sebuah state of the art dari fenomenologi dimaksud, yaitu suatu penjelasan sejarah kemunculan sebuah teori, perkembangan atas dasar penjabaran oleh teori-teori yang datang berikutnya serta perkembangan mutakhirnya.
\end{abstract}

Kata kunci: Paradigma, komunikasi fenomenologi, ontology, epistomologi, logic, ethisc.

\begin{abstract}
The main paradigm of the sociology of social facts, definitions of social and social behavior actually tried to explain the tug individual or known by the actors and the public, including the structure in it. The question was whether individuals who affect the structure or structures dominate the individual, so it has no other choice to act. There were other approaches that are radical in the sense of rejecting prablization orthodoxies 'structural functionalism' which became mainstrem, stamp given to the synthesis of Talcott Parson on organisms Durkheim and Weber's Theory of Social Action mendiminasi social theory after the Second World War, namely phenomenology. The world-life in the sense of Husserl mostly means that, as humans live in a world of spontaneity as a base act of communication between subjects. This is a life-world elements that make up the everyday of our reality, the elements of the world that everyday we live \& involved it before reflected and theorized philosophically. Phenomenology considered communication as a process of dividing the personal experiences through dialogue or conversation. Phenomenology is different disciplines of but still have a relationship with the discipline in the field of philosophy, such as ontology, epistemology, logic and ethics. The differences of knowledge discovery on phenomenology is rule out all theories, opinions and views are already known by every one, in purpose to capture the pure essence. As a measuring is inter-subjective truth, knowledge truth if to explore the meaning behind the phonemenon neomenon towards meta-theory and meta-science. The step methods used are (1) Phenomenological Reduction, (2) Eidetic Reduction, (3) Transcendental Reduction. This article will describe a state of the art of phenomenology in question, which is an explanation of the history of the emergence of a theory, the development on the basis of the translation by the theories that come next and its evolutions.
\end{abstract}

Keywords: Paradigm, communication, phenomenology, ontology, epistemology, logic, Ethisc. 


\section{PENDAHULUAN}

\subsection{Awal Pertumbuhan Fenomenologi}

Fenomenologi adalah gerakan filsafat yang dipelopori oleh Edmund Husserl (1859 - 1838). Salah satu arus pemikiran yang paling berpengaruh pada abad ke-20. Sebut saja para filsuf seperti Ernst Cassier (neoKantianisme), Mc.Taggart (idealisme), Fregge (logisisme), Dilthey (hermeneutika) Kierkergaard (filsafat eksistensial), Derrida (poststrukturalisme) semuanya sedikit banyak mendapat pengaruh dari fenomenologi.

Fenomenologi mencoba menepis semua asumsi yang mengkontaminasi pengalaman konkret manusia. Ini mengapa fenomenologi disebut sebagai cara berfilsafat yang radikal. Fenomenologi menekankan upaya menggapai "hal itu sendiri" lepas dari segala presuposisi. Langkah pertamanya adalah menghindari semua konstruksi, asumsi yang dipasang sebelum dan sekaligus mengarahkan pengalaman.

Tak peduli apakah konstruksi filsafat, sains, agama, dan kebudayaan, semuanya harus dihindari sebisa mungkin. Semua penjelasan tidak boleh dipaksakan sebelum pengalaman menjelaskannya sendiri dari dan dalam pengalaman itu sendiri. Fenomenologi menekankan perlunya filsafat melepaskan diri dari ikatan historis apapun apakah itu tradisi metafisika, epistimologi, atau sains.

Program utama fenomenologi adalah mengembalikan filsafat ke penghayatan sehari-hari subjek pengetahuan. Kembali ke kekayaan pengalaman manusia yang konkret, lekat, dan penuh penghayatan. Selain itu, fenomenologi juga menolak klaim representasionalisme epistimologi modern. Fenomenologi yang dipromosikan Husserl sebagai ilmu tanpa presuposisi. Ini bertolak belakang dengan modus filsafat sejak Hegel menafikan kemungkinannya ilmu pengetahuan tanpa presuposisi.

Presuposisi yang menghantui filsafat selama ini adalah naturalisme dan psikologisme. Pengaruh fenomenologi sangat luas. Hampir semua disiplin keilmuan mendapatkan inspirasi dari fenomenologi. Psikologi, sosiologi, antropologi, sampai arsitektur semuanya memperoleh nafas baru dengan munculnya fenomenologi.

Penyamarataan ilmu-ilmu humaniora dengan ilmuilmu mendapatkan tentangan keras dari filsuf-filsuf neo-Kantian yang menginginkan adanya pemilahan, baik sacara metodologis, ontologis, dan epistimologis antara ilmu- ilmu humaniora dan ilmu-ilmu alam. Para Kantian merasa bahwa manusia tidak sematamata ditentukan oleh hukum maupun bertindak secara rasional semata (animal rationale), melainkan juga memiliki kekayaan batin (emosi, kehendak, disposisi) yang tidak dapat diukur begitu saja dengan model-model ilmu alam.

Salah satu neo-Kantian dari Mahzab Marburg bernama Ernst Cassier mengungkapkan konsepnya tentang manusia sebagai animal symbolicum (makhluk simbolik) konsepnya ini menentang konsep manusia yang dideterminasi oleh daya-daya atau stimulan-stimulan eksternal seperti halnya bendabenda fisik. Cassier menolak pandangan naturalisme yang dianut ilmu-ilmu alam (ada realitas material eksternal yang berjalan secara deterministik dan independen dari subjek).

Untuk lebih memberikan pembahasan tentang sejarah awal lahirnya fenomenologi kita mulai dengan membahas fenomenologi Edmund Husserl sebagai berikut yaitu Edmund Husserl ${ }^{1}$ lahir di kota kecil Prossnit di daerah Moravia pada 8 April 1859. Saat itu Prossnit masuk dalam wilayah kekaisaran AustriaHongaria. Sejak akhir perang dunia I tahun 1918 masuk dalam wilayah Cekoslowakia dan saat wilayah ini dibagi dua masuk ke wilayah Republik Ceko.

Berasal dari keluarga Yahudi golongan menengah. Nama Husserl nampaknya berasal dari kata Iserle (=Israel). Pada usiaa 27 tahun Husserl dibabtis dalam Gereja Kristen Protestan atas pengaruh sahabatnya G. Albrecht. Gelar Doktor Filsafat diraihnya dengan sebuah desertasi tentang matematika yang berjudul Beiträge zur Variatiosrechnung (1883). Kemudian menulis untuk Habilitationschift ${ }^{2}$ yang berjudul Ueber den Begrif der Zahl (1887) tentang konsep bilangan. Setelah itu barulah diangkat sebagai privatdozent $^{3}$ (dosen) di Halle (1887- 1901).

\footnotetext{
${ }^{1}$ Viktor Velarde Mayol, On Husserl (USA: Belmont, tt), 3-4

${ }^{2}$ Habilitationschift adalah karya tulis yang harus disusun oleh setiap sarjana (setelah meraih doktornya) sebelum mendapatkan ijin mengajar di Universitas. Sebuah tradisi ilmiyah yang cukup ketat di Jerman untuk seseorang memperoleh wewenang mengajar.

3 Privatdozent, adalah istilah yang digunakan di UniversitasUnversitas Jerman untuk seseorang dosen yang diizinkan mengajar tetapi tidak mendapatkan gaji tetap dari Universitas, ia hidup dari kuliah yang diberikannya. Kira-kira kalau di Indonesia disebut dosen honorer, bukan dosen tetap.
} 
Husserl melanjutkan penelitiannya tentang filsafat matematika dan sebagai sebagai hasil studinya diterbitkan buku Philosophie der Arithmetik. Psychologische und logische Untersuchngen (1891) (Filsafat ilmu berhitung. Penelitian-penelitian psikologis dan logis). Sepuluh tahun berikutnya Husserl memperdalam dan merevisi pemikirannya tentang pokok yang sama, antara lain karena ktirik G., Frege -seorang filsuf dan matematikus ternama -- atas buku di atas. Sesudah sepuluh tahun barulah dapat menerbitkan Logische Untersuchungen (2 jilid: 19001901), yaitu sebuah penelitian tentang logika. Buku ini dianggap sebagai permulaan fenomenloginya. Dalam jilid pertama buku tersebut Husserl mengkritik dan menolak psikologisme dalam filsafat tentang logika.

Menurut psikologisme keharusan logis itu tidak lain daripada keharusan yang menandai cara berpkir kita. Dengan lain perkataan, psikologisme mengasalkan logika dari psikologi. Pandangan ini tersebar luas dalam kalangan filsafat abad ke-19, terutama John Stuart Mill (1806 - 1973). Sampai saat itu Husserl sendiri juga penganuh psikologisme. Dalam buku itu Husserl meyakinkan bahwa pandangan psikologisme tidak dapat lagi dipertahankan.

Dalam sebuah diary dia menuliskan "I have been through enough torments from lack of clarity and from doubt that waves back and forth... Only one need absorbs me: I must win clariy, else I cannot live; I cannot bear life unless I can believe that I shall achieve it." (Aku sudah cukup menderita dari kurangnya kejelasan dan dari keraguan seperti gelombang pasang surut ... Hanya satu hal yang aku butuhkan: Aku harus menemukan kejelasan, kalau tidak aku tak dapat hidup; Aku tidak dapat bertahan hidup kecuali aku dapat mempercayai bahwa aku akan mencapainya).

Di sini persoalan kejelasan dan kepastian menjadi persoalan yang utama dalam membangun fenomenologi.

\section{TINJAUAN PUSTAKA}

Tinjauan Pustaka merupakan bagian yang sangat penting dari penelitian karena pada bab ini diungkapkan pemikiran atau teori-teori yang melandasi dilakukannya penelitian. Teori yang disajikan tersebut menerangkan hubungan antara beberapa konsep yang

\footnotetext{
${ }^{4}$ Viktor Velarde Mayol, On Husserl, 5
}

digunakan untuk menjelaskan masalah penelitian, yang kemudian digunakan kembali untuk menjabarkan menjadi variabel-variabel.

Kegiatan tinjauan pustaka yang dilakukan yaitu meliputi pencarian, membaca dan mendengarkan laporan-laporan penelitian dan bahan pustaka yang memuat teori-teori yang relevan dengan penelitian yang akan dilakukan.

\subsection{Filsafat Edmund Husserl}

Fenomenologi merupakan bentuk dari idealisme yang semata-mata tertarik pada struktur-struktur dan caracara bekerjanya kesadaran manusia serta dasardasarnya. Dunia yang kita huni, dalam pandangan fenomenologi, merupakan ciptaan dari kesadarankesadaran yang ada di dalam kepala individu masing masing. Proses bagaimana manusia membangun dunianya adalah melalui proses pemaknaan yang berawal dari arus pengalaman.

Fenomenologi menempatkan peran individu sebagai pemberi makna, dan dari proses pemaknaan oleh individu inilah yang kemudian menghasilkan tindakan yang didasari oleh pengalaman sehari-hari yang bersifat intensional. Individu kemudian memilih sesuatu yang "harus" dilakukan berdasarkan makna tentang sesuatu, dan mempertimbangkan pula makna objektif (masyarakat) tentang sesuatu tersebut.

Dalam sebuah artikel yang cukup panjang, "Pure Phenomenology (1917)", Husserl merumuskan citacitanya untuk mendasari filsafat sebagai suatu ilmu yang rigorus (rigorous science) dan kepada ilmu ini ia beri nama 'fenomenologi'. Fenomenologi adalah ilmu pengetahuan (logos) tentang apa yang tampak (phainomenon). Jadi, seperti sudah tersirat dalam namanya fenomenologi mempelajari apa yang tampak atau apa yang menampakkan diri atau fenomena.

Tetapi dengan itu dimaksudkan Husserl sesuatu yang pada waktu itu sama sekali baru. "Fenomena" sama sekali bukan sebagaimana yang dimengerti oleh Kant. Menurut Kant, kita manusia hanya mengenal fenomenon dan bukan numenon, kita hanya mengenal fenomena-fenomena (Erscheinungen) dan bukan relaitas itu sendiri (das ding an sich).

Bagi Kant (dan juga empirisme Inggris), yang tampak bagi kita semacam tirai yang menyelubungi realitas di belakangnya. Kita hanya mengenal pengalaman batin kita sendiri yang --entah bagaimana-diakibat- 
kan oleh realitas di luar yang tetap tinggal suatu $\mathrm{x}$ yang tidak kita kenal. Melihat warna merah, misalnya, tak lain tak bukan adalah pencerapan (sensation), -- jadi pengalaman batin -- yang diakibatkan oeleh sesuatu di luar.

Bagi Kant fenomena adalah sesuatu yang menjuk kepada realitas, yang tidak dikenal in se (pada dirnya). Dalam perspektif ini kesadran dianggap tertutup dan terisolir dari realitas. Seluruh konsepsi Kant ini dilatarbelakangi filsafat Descartes (cogito, tertutup). Yang dimaksud Husserl "fenomena" adalah sesuatu yang sama sekali lain. Bagi Husserl, fenomena ialah realitas sendiri yang tampak. Bagi dia, tidak ada selubung atau tirai yang memisahkan kita dari realitas; realitas itu sendiri tampak bagi kita.

Dengan demikian dapat kita mengertai semboyan yang dipilih Husserl bagi filsafatnya, yaitu Zurück zu den sachen selbst (Back to thing themselves), kembalilah pada benda-benda sendiri. Ungkapan ini memiliki beberapa makna, yaitu: pertama, awal dari sesuatu itu kembali kepada apa yang bersifat obyektif (logika, etika dll) sebagai suatu obyek dari kesadaran (intensional object). Kedua, hal tersebut merupakan sebuah reaksi dari empirisme Hume dan idealisme transendental Kant. Ketiga, mungkin juga berarti bahwa makna yang digunakan secara luas adalah merupakan reaksi terhadap skeptisisme dan relativisme yang menolak ide tentang obyektifitas universal. $^{5}$

Dengan pandangan tentang fenomena ini Husserl mengadakan semacam revolusi dalam filsafat Barat. Dalam filsafat Barat sejak Descartes, kesadaran selalu dimengerti sebagai kesadaran tertutup atau cogito tertutup; artinya, kesadaran mengenal diri sendiri dan hanya melalui jalan itu mengenal realitas. Misalnya, saya mengenal pencerapan-pencerapan (sensations) saya dan melalui jalan itu saya mengenal realitas.

Husserl berpendapat bahwa kesadaran menurut kondratnya terarah pada realitas. Kesadaran selalu berarti kesadaran akan sesuatu. Atau menurut istilah yang dipakai Husserl, kesadaran menrurut kodratnya bersifat intensional; intensionalitas ${ }^{6}$ adalah struktur

\footnotetext{
${ }_{6}^{5}$ Ibid, 11

6 Husserl menggunakan istilah 'intensionalitas' berasal dari Brentano, namun Brentano memiliki maksud lain dengan istilah ini, sehingga ajaran intensionalitas dapat diklaim sebagai penemuan khas Husserlian Baca: Harvie Fergusen, Phenomenology
}

hakiki kesadaran. Karena kesadaran yang ditandai oleh intensionalitas inilah, fenomena harus dimengerti sebagai apa yang menampakkan diri. Mengatakan 'kesadaran bersifat intensional' sebenarnya sama artinya dengan mengatakan 'realitas menampakkan diri'.

Dua hal di atas 'fenomena' dan 'intensionalitas' seperti dua sisi dari mata uang logam yang sama, keduanya korelatif. Korelasi ini berlakubagi kesadaran dan realitas pada umumnya, tetapi juga bagi pelbagai aktus kesadaran dan realitas, misalnya, pengalaman estetis --obyek estetis (karya kesenian).

Dua istilah kunci dalam filsafat Husserl telah kita bahas, yaitu 'fenomena' dan 'intensionalitas', selanjutnya istilah lain yang juga digunakan oleh Husserl berkenaan dengan kedua istilah tadi adalah 'konstitusi' (constitution). Konstitusi adalah proses tampaknya fenomena-fenomena kepada kesadaran. Dan karena adanya korelasi antara kesadaran dan realitas yang disebut tadi, dapat dikatakan juga bahwa konstitutsi adalah aktivitas kesadaran yang memungkinkan tampaknya realitas.

Kata Husserl dunia real dikonstitusi oleh kesadaran. ${ }^{7}$ Hal tersebut sama sekali tidak berarti bahwa kesadaran mengadakan atau menyebabkan dunia beserta pembedaan-pembedaan yang terdapat di dalamnya, melainkan hanyalah bawah kesadaran harus hadir pada dunia supaya penampakan dunia dapat berlangsung.

Pokok ajaran berikutnya dari Husserl adalah pendiriannya tentang "reduksi fenomenologis" atau "reduksi transendental", yang Husserl sendiri menyebutnya sebagai Epoché8 (kata Yunani yang dipinjam dari filsafat Heelnistis). Apa sesungguhnya yang dimaksud reduksi oleh Husserl?. Dalam kehidupan biasa kita selalu condong untuk mengandaikan bahwa dunia sungguh-sungguh ada sebagaimana diamati dan dijumpai. Dengan diam-diam kita percaya pada adanya. Sikap ini oleh Husserl disebut 'sikap natural' (natural attitude). Untuk memulai fenomenologi, kita harus mengubah sikap ini.

Kita harus menghentikan -atau lebih tepat menangguhkan-kepercayaan kita pada dunia real. Kita harus meletakkan adanya dunia real diantara kurung. Di

and Social Theory dalam George Ritzer \& Barry Smart, Handbook of Social Theory (London : SAGE, 2001), 236

${ }^{7}$ Ibid.

8 Viktor Velarde Mayol, On Husserl,47. Baca juga Harvie Fergusen, Phenomenology and Social Theory, 238 
sini nampak adanya kemiripan jalan pikiran dengan metode Descartes. Namun demikian, Husserl tidak boleh disamakan dengan kesangsian metode Descartes. Reduksi tidak merupakan kesangsian terhadap dunia, melainkan semacam netralisasi: ada tidaknya dunia real tidak mempunyai peranan lagi. Bagi Descartes kesangsian berarti: mungkin dunia ada, mungkin tidak. Bagi Husserl reduksi berarti: ada tidaknya dunia real tidak relevan: persoalan ini dapat disisihkan tanpa merugikan. Dengan mempraktikkan reduksi ini kita masuk "sikap fenemenologis". Konsep reduksi ini sangat terkait dengan cita-cita Husserl akan fenemenologi sebagai ilmu yang rigorus. Ilmu yang rigorus tidak boleh mengandung keraguan, ketidakpastian atau kedwiartian apapun juga.

Ucapan-ucapan yang dikemukakan dalam suatu ilmu yang rigorus harus bersifat apodiktis (tidak mengizinkan keraguan) dan absolut (tidak mengizinkan perkembangan dan perubahan lebih lanjtu). Kriteria rigorus itu tidak pernah dapat dipenuhi dalam ucapan-ucapan kita tentang dunia real. Suatu benda material tidak pernah diberikan kepada kita secara apodiktis dan absolut. Setiap benda maerial selalu diberikan melalui profil-profil (Abschattungen).

Misalnya saja, dari meja yang berdiri saya tidak melihat sebelah belakang. Tentu saja, saya bisa memilih sudut lain, sehingga saya melihat sebagai belakang itu. Tetapi kalau demikian, saya tidak melihat lagi sebelah depan dan profil-profil lainnya. Inilah cara benda material tampak bagi saya: berkeluasan dan ruang.

Suatu benda meterial tidak pernah diberikan kepada saya profilnya, secara total dan absolut. Cara realitas material tampaknya bagi saya bersifat demikian rupa, sehingga tidak dapat dikemukakan pernyataan-pernyatasan apodiktis dan absolut tentangnya. Karena alasan-alasan itu fenomenologi sebagai ilmu rigorus harus mulai dengan mempraktikkan reduksi transendental.

Jika kita menempatkan realitas meterial antara tanda kurung dengan mempraktikkan reduksi transendental tersebut, apakah yang tinggal untuk mendasari fenomenologi sebagai rigorus? Atauhkan harus kiga meninggalkan saja sejauh usaha kita? Husserl berpendapt bahwa yang tinggal adalah kesadaran atau subyketivitas.

Kesadaran tidak berkeluasan dalam ruang. Kesadaran tampak bagi saya secara total dan langsung. Karena ini menjadi meungkin mengemukakan pernyataanpernyataan apodiktis dan absolut tentangnya. Adanya kesadaran juga struktur kesadaran dapat dinyatakan secara absolut. Jadi kesadaran harus dipilih sebagai dasar bagi fenomenologi sebagai ilmu rigorus.

Lantas apa yang terjadi dengan dunia real? Apakah hal itu berarti bahwa fenomenologi sama sekali tidak dapat berbicara tentang dunia ? Tentu tidak. Jangan lupa dengan intensionalitas kesadaran yang sangat dipentingkan oleh Husserl. Reduksi justru menyingkirkan kesadaran sebagai -- menurut kodratnya -- terarah pada dunia, sebagai intensionnal. Dengan demikian dunia mendapat tempatnya lagi dalam fenomenologi. Kita tidak bisa lagi berbicara tentang dunia dengan cara yang naif, yaitu dunia yang sama sekali tidak ada kaitannya dengan kesadaran.

Tetapi dalam sikap fenomenologis kita menemui dunia sebagai korelat bagi kesadaran, dunia sebagai fenomena. Dalam fenomenologi kita tidak bertolak belakang dengan dunia; sebaliknya, realitas material ditemui dalam suatu perspektif baru, yaitu sebagai korelat bagi kesadaran.

Tentang reduksi, yang terpenting bagi Husserl bukanlah meletakkan dunia sendiri antara kurung, melainkan terutama setiap interpretasi atau teori tentang dunia. Ia juga semakin menekankan aspek positif dari reduksi: reduksi bukan saja berarti berpaling dari dunia seperti dimengerti dalam sikap natural, melainkan juga terutama berpaling kepada sesuatu, yaitu kesadaran atau ego transendental.

\subsection{Perkembangan Kontemporer Fenomenologi}

Sebagaimana diungkapkan pada awal tulisan ini, bahwa fenomenologi merupakan arus pemikiran yang paling berpengaruh pada abad 20. Hampir seluruh disiplin ilmu terinspirasi oleh pendekatan ini, misalnya studi agama. Agama yang selama ini dikaji dengan kerangka positivisme disetarakan dengan "mitos" dan karenanya diramalkan akan tenggelam dilibas oleh kekuatan "ideologi" dan "ilmu pengetahuan". Waardenberg, dalam karyanya Classical Approaches to the Study of Religion (1973) menggunakan term kunci "empiris" dan "rasional" dalam meneliti agama.

\footnotetext{
${ }^{9}$ Peter Connolly, Aneka Pendekatan Studi Agama (Yogyakarta: LKiS, 2002), 106
} 
Emprisme dan Rasionalisme sebagai sebuah metode diderivasi dari ilmu-ilmu kealaman yang diterapkan ke dalam ilmu sosial sebagai suatu pengujian terhadap struktur sosial dan perilaku manusia. Rasional mengacu pada penelitin perilaku manusia sesuai dengan premis-premis dan penemuan pengetahuan ilmiyah.

Oleh karena itu, irasional mengindikasikan agama sebagai suatu fenomena yang tidak berjalan sesuai dengan parameter-parameter tersebut. Ini memunculkan pertanyaan, apakah agama merupakan aktivitas rasional dan apakah agama harus dipahami sebagai seuatu wilayah pengetahuan atau dibiarkan sebagai suatu yang ketinggalan zaman, dan mungkin takhayul dari aktivitas manusia yang dinamakan "prailmiyah". Inilah substansi kritik Freud dan kecenderungan analisis-analisis lainnya, khususnya Feuerbach dan Marx.

Fenomenologi hadir untuk menunjukkan bahwa agama perlu dikaji secara serius dan memberi kontribusi terhadap pemahaman kita tentang humanitas dengan cara yang positif. Hal ini mengharuskan kita segera tanggap terhadap fakta bahwa studi agama tidak dapat menjadi penelitian yang murni obyektif tetapi harus mempertimbangkan keterlibatan peneliti dalam subyek penelitian itu sendiri.

Fenomenologi agama tidak muncul di luar perdebatan mengenai apakah studi agama merupakan penelitian ilmiah?, tetapi berangkat dari evaluasi atas pendekatan yang mendahuluinya, dan berusaha menetapkan kerangka kerja metodologisnya sendiri dalam studi agama dalam kaitannya sebagai pendekatan alternatif terhadap subyek agama. Dengan fenomenologi, para fenomenolog mulai menyelidiki dunia agama melalui upaya-upaya kolektif, menemukan bahwa dunia ini sulit dipetakan.

Fenomenologi agama telah memberikan kontribusi dan dapat menjadikan penelitian tentang signifikansi agama dalam kehidupan manusia secara terus menerus. Karya-karya penelitian tentang agama yang mutakhir banyak dihasilkan dengan menggunakan pendekatan fenomenologi ini.

\section{METODE PENELITIAN}

Metode penelitian dalam penulisan artikel ilmiah ini adalah menggunakan metode kualitatitf deskriptif melalui studi kepustakaan dengan menganalisa perspektif fenomenologi yang berkembang di masyarakat lalu mengkajinya dengan pijakan teori dan analisa teori tentang fenomenologi khususnya pada realitas sosial pandangan Edmund Husserl agar dapat mengambil suatu kesimpulan untuk hasil penelitian.

\section{HASIL DAN PEMBAHASAN}

Bab ini memuat gagasan peneliti yang terkait dengan apa yang telah dilakukan dan apa yang diamati, dipaparkan dan dianalisis di bab terdahulu. Uraian mengenai gagasan ini dikaitkan dengan hasil kajian teori dan hasil-hasil penelitian lain yang relevan. Untuk hal ini dilengkapi dengan implikasi dari temuan penelitian.

\subsection{Perspektif Fenomenologi}

Jika positivisme amat gila terhadap penyusunan teori, fenomenologi boleh dikatakan menolak teori. Fenomenologi sedikit alergi teori. Pendekatan ini lebih menekankan rasionalisme dan realitas budaya yang ada. Hal ini sejalan dengan penelitian etnografi yang menitikberatkan pandangan warga setempat. Realitas dipandang lebih penting dan dominan dibanding teori-teori melulu.

Fenomenologi berusaha memahami budaya lewat pandangan pemilik budaya atau pelakunya. Menurut paham fenomenologi, ilmu bukanlah values free, bebas nilai dari apa pun, melainkan values bound, memiliki hubungan dengan nilai. Aksioma dasar fenomenologi adalah:

a. kenyataan ada dalam diri manusia baik sebagai indiividu maupun kelompok selalu bersifat majemuk atau ganda yang tersusun secara kompleks, dengan demikian hanya bisa diteliti secara holistik dan tidak terlepas-lepas;

b. hubungan antara peneliti dan subyek inkuiri saling mempengaruhi, keduanya sulit dipisahkan;

c. lebih ke arah pada kasus-kasus, bukan untuk menggeneralisasi hasil penelitian;

d. sulit membedakan sebab dan akibat, karena situasi berlangsung secara simultan;

e. inkuiri terikat nilai, bukan values free.

Dalam pandangan Natanton (Mulyana, 2002:59) fenomenologi merupakanistilah generik yang merujuk kepada semua pandangan ilmu sosial yang menganggap bahwa kesadaran manusia dan makna subjektif sebagai fokus untuk memahami tindakan sosial. Tentu saja, dalam kaitannya dengan penelitian budaya pun pandangan subjektif informan sangat diperlukan. Subjektif akan menjadi sahih apabila ada proses intersubjektif antara peneliti budaya dengan informan. 
Wawasan utama fenomenologi adalah "pengertian dan penjelasan dari suatu realitas harus dibuahkan dari gejala realitas itu sendiri" (Aminuddin, 1990 : 108). Dalam perkembangannya, fenomenologi memang ada beberapa macam, antara lain: (a) fenomenologi Edidetik dalam linguistik, (b) fenomenologi Ingarden dalam sastra, artinya pengertian murni ditentukan melalui penentuan gejala utama, penandaan dan pemilahan, penyaringan untuk menentukan keberadaan, penggambaran gejala (refleksi), (c) fenomenologi transendental, dan (d) fenomenologi eksistnsial.

\subsection{Fenomenologi dan Ontologi, Epistemologi, Logika, Etika}

Fenomenologi merupakan salah satu bentuk disiplin dasar di filsafat. Bagaimana fenomenologi menjadi bentuk yang terkenal dan bagaimana hubungannya dengan bidang filsafat yang lain? Secara tradisional, filsafat paling tidak empat bidang inti atau disiplin, yaitu: Ontologi, epistemology, etika, dan logika. Misalkan fenomenolofi digabungkan menjadi satu daftar dengan ilmu filsafat yang lain, maka pandang definisi dasar berikut:

- Ontology is the study of beings or their being what is.

- Epistemology is the study of knowledge - how we know.

- Logic is the study of valid reasoning - how to reason.

- Ethics is the study of right and wrong - how we should act.

- Phenomenology is the study of our experience how we experience.

Domain dari ke lima studi tersebut berbeda secara jelas dan metode studinya juga berbeda.

Para filsafat terkadang setuju bahwa salah satu dari lima ilmu filsafat tersebut terdapat 'fistt philosophy', disiplin ilmu filsafat yang paling fundamental, dimana semua filsafat atau semua pengetahuan atau wisdom bersandar. Secara historis, Socrates dan Plato adalah orang pertama yang menanamkan filsafat etika, kemudian Aristoteles orang pertama yang menananmkan filsafat metafisika atau ontology, selanjutnya Descrates orang pertama yang menanamkan filsafat epistemology, kemudian Russel orang pertama yang menanamkan filsafat etika dan Husserl orang pertama yang menanamkan fenomenologi. Sekarang pandang filsafat epistemology. Seperti yang kita lihat, menurut epistemology modern, fenomenologi membantu untuk mendefinisi- kan fenomena dimana klaim pengetahuan berada. Sebaliknya, fenomenologi sendiri mengklaim untuk menerima pengetahuan tentang alam kesadaran, seseorang (orang pertama yang khusus) harus mengetahui pengetahuan melalui betuk intuisi (experience).

Sekarang pandang logika. Pemkanaan teori logika membawa Husserl ke dalam teori intensionalitas, jantung dari fenomenologi. Dalam satu riwayat, disebutkan bahwa fenomenologi menguraikan intensional atau semantic force dari makna ideal dan makna proposional adalah pusat terhadap teori logika. Namun, struktur logika diekspresikan dalam bahasa, begitu juga dengan bahasa asli atau bahasa symbol. Yang tersisa adalah isu penting tentang perdebatan dimana dan apakah bahasa membentuk bentuk experience kusus (pemikiran, persepsi, emosi) dan sebagainya yang memilki kesamaan makna. Sehingga terdapat hubungan yang penting antara fenomenologi dengan teori lingustik logika, terutama filsafat logika dan filsafat bahasa (sebagai lawan terhadap logika matematika).

Sekarang pandang Ontologi. Fenomenologi mempelajari alam kesadaran, yang merupakan isu sentral dalam ontology dan salah satunya berperan terhadap permasalahan tradisional mind-body. Metodologi Husserlian akan mengurung pertanyaan tentang eksistensi dari dunia sekelilingnya. Fenomenologi Husserl masih menduga teori tentang spesies dan individi (universal dan particular), hubungan antara sebagian dan seluruhnya dan makna ideal — semuanya merupakan bagian dari ontology.

Sekarang pandang etika. Fenomenologi mungkin memainkan peranan di etika dalam menawarkan analisis dari struktur keinginan, penghargaan, kebahagiaan dan kepedulian terhadap yang lain (dalam simpati dan empati). Secara historis, meskipun,etika telah berada pada batas pemikiran fenomenologi. Husserl secara luas menghindari etika dalam pekerjaan utamanya, meskipun demikian Husserl menonjolkan aturan praktik yang berhubungan dengan struktur life-world, dan Husserl pada suatu waktu menyampaikan kursus perkuliahan penrimaan etika (seperti logika) sebagai tempat dasar filsafat, yang mengindikasikan pentinganya fenomenologi terhadap, simpati dalam grounding ethics. Dalam Being and Time, Heidegger mengklaim tidak mengikuti etika ketika mendiskusikan range fenomena dari kepedulian, kesadaran dan kesalahan terhadap 'fallennes' dan 'authenticity' (semua fenomena dengan teologi echoes). 
Bergabung dengan etika adalah filsafat social dan politik. Sarte dan Merleau-Ponty menyatakan teori politik berdasarkan kebebasan individu. Teori politik berada pada fenomenologi. Teori Sosial sangat dekat dengan fenomenologi. Husserl menganalisis struktur fenomenologi dari life-world secara umum meliputi aturan-aturan dalam aktifitas social. Heidegger menekankan praktik social, yang dia temukan lebih pokok daripada kesadaran indifidu. Alferd Schutz mengembangkan fenomenologi tentang dunia social. Sartre melanjutkan penaksiran fenomenologi terhadap pemaknaan yang lainnya, seperti fundamental pembentuk social. Michel Foucault mempelajari genesis dan pemknaan institusi social dari penjara ke tempat pengasingan, yang merupakan isu dari fenomenologi. Dan Jacques Derrida telah melakukan studi yang panjang tentang fenomenologi bahasa, mencari pemaknaan social dalam "deconstruction".

Sejak saat itu, fenomenologi klasik meletakkan fenomenologi ke dalam area tertentu di epistemology, logika dan ontology dan berperan pada bagian teori etika, sosial dan politik.

\subsection{Fenomenologi sebagai Alat Menemukan Pengetahuan}

Realitas Objek tidak bisa dilepaskan dari kehidupan sehari-hari subjek yang menampakkan diri sebagaimana adanya. Husserl mengatakan, fenomena adalah realitas sendiri yang tampak. Di mana segala tirai yang memisahkan manusia dengan realitas tidak ada lagi, dengan begitu realitas itu sendiri tampak bagi manusia. Inilah yang dalam semboyan filsafat Husserl dikatakan: Zurruck zu den sachen selbst (kembali kapada benda itu sendiri) (Bertens, 1983: 101).

Realitas objek yang tampak di hadapan subjek ditangkap oleh kesadaran itu adalah intensional. Dengan mengatakan kesadaran bersifat intensional sebenarnya sama artinya mengatakan realitas menampakkan diri. Husserl menjelaskan intensionalitas merupakan struktur hakiki kesadaran (Bertens, 1983)). Intensionalitas adalah istilah yang berasal dari kata intedere, yang artinya menuju ke. ${ }^{10}$ Dalam intensionalitas ingin mengatakan bahwa objek adalah selalu melihat dengan subjek, dan tidak bisa dipahami berdiri sendiri. ${ }^{11}$ Istilah intensionalitas juga digunakan

\footnotetext{
${ }^{10}$ Hamersma, Tokoh-Tokoh Filsafat Barat Modern, (Jakarta: Gramedia, 1983), 117

${ }^{11}$ Shofiyullah Mz, Opcit, 256
}

oleh psikologi, yang berpandangan bahwa tidak ada hal yang menyadari tanpa ada yang menyadari. Begitu juga tak ada yang dilihat, tanpa ada yang melihat.

Tampaklah dari penjelasan yang dipaparkan di atas hal tersebut mengisyaratkan adanya suatu sintesis antara subjek dan objek (Brower, 1983). Jadi dalam intensionalitas tidak ada dikotomi antara subjek dan objek. Setiap pandangan subjek mempengaruhi objek. Fenomenologi berangkat dari pra pengalaman empiris dan membebaskan segala bentuk teori pengetahuan, dengan tidak memberikn penilaian dan interpretasi terhadap objek yang menampakkan dalam kesadaran, dengan cara menangguhkan atau menunda penilaian interpretasi untuk menemukan hakikat. Hakikat tidak terletak di belakang atau di atas peristiwa, tetapi berada di dalamnya. ${ }^{12}$ Intensionalitas bagi Husserl bersifat kesadaran transendental yang berarti kesadaran yang selama memurnikan dari semua atau segala unsur-unsur transenden, yakni dari semua bahan-bahan dunia (Beerling, 1958). Semua bentuk teori dan konsep telah disingkirkan, maka yang tinggal adalah evidensi (kenyataan/ kejelasan). Kesadaran bagi Husserl adalah titik sama dengan kesadaran yang terdapat pada Descartes. Kesadaran Descartes adalah kesadaran yang tertutup. Setelah semuanya kesadaran disangsikan oleh Descartes, maka yang tinggal adalah "aku yang sedang berpikir", aku yang sedang berpikir ada, adalah sangat subjektif, dan ini dikatakan kesadaran Descartes tertutup. Kesadaran terbuka adalah mengarahkan kepada objketifikasi realitas, yaitu kembali kepada benda itu sendiri, dengan keterbukaan yang terus menerus pada objek.

\subsection{Tolok Ukur Kebenaran}

Kebenaran ialah yang terkandung dalam suatu pengetahuan. Pada pengetahuan nilai kebenaran tergantung pada cara atau bagaimana memperoleh pengetahuan, sikap pada subjek dalam mencoba untuk menggali sebuah kebenaran, sarana yang dipergunakan untuk mengamati objek.

Kemudian tidak kalah pentingnya kebenaran pengetahuan tergantung pada kualitas dan karakteristik pengetahuan, relasi subjek dan objek, serta kandungan nilai yang melekat pada pengetahuan, apa ia

\footnotetext{
12 Beerling R. F, 1958, Filsafat Dewasa Ini Jilid 2, Kanisius, Yogyakarta, 64
} 
objektif kebenarannya atau subjektif. ${ }^{13}$ Fenomenologi Husserl yang menjadi tolok ukur kebenarannya adalah intersubjektif. Ia berpandangan bahwa pengetahuan mempunyai nilai benar jika melakukan eksplorasi makna noumenon di balik yang phenomenon menuju ke metateori atau metasains. Makna noumenon dapat mengacu pada acuan monolitik, kemudian boleh juga mengembangkan alternatif acuan divergen. ${ }^{14}$

Melihat suatu objek akan menghasilkan interpretasi yang berbeda-beda, setelah diamati oleh subjek, kemudian dari interpretasi yang berbeda-beda tersebut dalam intersubjektif harus menuju konsensus bersama.

\subsection{Objek Pengetahuan}

Objek pengetahuan menurut Husserl adalah realitas sendiri yang menampakkan diri sendiri pada kita, melalui kesadaran yang intensional. Suatu fenomenon tidak mesti dapat diamati oleh indera yang lima buah itu, sebab fenomenon dapat juga dilihat dan diamati secara rohani, tanpa melalui indera, dan fenomen bukan suatu peristiwa. ${ }^{15}$ Realitas yang nampak tersebut kemudian dipahami dengan menggunakan intuisi. Inutuisi menurut Husser adalah kesadaran atau mempunyai kesadaran yang dapat di pandang secara sadar. $^{16}$

\section{KESIMPULAN}

Untuk lebih memberikan pemahaman yang lebih jelas, berikut beberapa statemen berupa kalimat negasi tentang fenomenologi:

- Fenomenologi bukan idealisme. Idealisme menggagas realitas dalam ketunggalan, keseluruhan, keuniversalan. Realitas dapat diringkas dalam idea, dalam apa yang seorang idealis memaksudkannya sebagai idea. Fenomenologi jauh dari pemaknaan idealis.

- Fenomenologi bukan formalisme. Artinya fenomenologi bukan suatu rincian pemikiran yang memiliki kategori-kategori formal, ketat, rigid. Formalisme berkaitan dengan disiplin ilmu-ilmu

\footnotetext{
${ }^{13}$ Abbas Hamimi Mintaredja, Teori Pengetahuan Menurut Berger, (Yogyakarta: 1983), 30

${ }^{14}$ Noeng Muhadjir, Filsafat Illmu: Positivisme, Post Positivisme dan Post Modernisme, Edisi 2, (Yogyakarta: Rake Yasin, 2001), 65

${ }^{15}$ Harun Hadiwijono, Sari Sejarah Filsafat Barat 2, (Yogyakarta: Kanisius, 1980), 64140

${ }^{16}$ Beerling R. F, 1958, opcit, 54
}

sosial yang memiliki target-target formal menggariskan metodologi sah, sahih, obyektif (dalam kacamata tuntutan ilmu mereka). Keketatan pendekatannya mengatasi batas-batas apa yang disebut sebagai sah, sahih, valid. Fenomenologi tidak memiliki ambisi formal apa pun.

- Fenomenologi bukan pula realisme. Realisme konteks epistemologis memiliki akar pandangan dari Aristoteles. Dalam filsafat Aristotelian, suatu pengetahuan memiliki pondasi kesesuaian/ ketidaksesuaian dengan obyek. Artinya, sebuah pengetahuan pasti berurusan dengan justifikasi, pembuktian, pembenaran validitas. Realisme menggagas bahwa setiap pembenaran berarti obyektivasi. Dengan demikian, soal validitas tidak lain dan tidak bukan adalah soal korespondensi/diskrepansi apa yang saya ketahui dalam akal budi dengan obyek/realitas dari yang saya ketahui tersebut. Obyektivisme merupakan paham yang memiliki ambisi universalisme suatu pengertian tentang realitas yang dalam fenomenologi - sangat tidak bisa diandaikan.

- Fenomenologi jelas juga bukan POSITIVISME yang meletakkan kebenaran sejauh diletakkan, diberlakukan. Misalnya "hukum"," agama", dogma", "tradisi", "opini koersif (dari instansi atau kelompok pemaksa)" Lantas Fenomenologi dekat dengan apa? Fenomenologi dekat sekali dengan eksistensialisme. Fenomenologi malahan menggarap dunia eksistensi manusia.

- Fenomenologi dapat menempatkan fenomena sosial sebagai sistem simbol, yang harus dipahami dalam kerangka konteks sosio-kultur yang membangunnya. Ini artinya unsur subjek dilihat sebagai bagian tak terpisahkan dari proses terciptanya suatu ilmu pengetahuan sekaligus mendapatkan dukungan metodologisnya.

- Fenomenologi melihat komunikasi sebagai sebuah proses membagi pengalaman personal melalui dialog atau percakapan. Fenomenologi juga cenderung menentang naturalisme (biasa juga disebut objektivisme atau positivisme).

\section{PENUTUP}

Fenomenologi adalah soal pengertian yang mendalam tentang subyektivitas pengertian tentang dunia. Ide berada dalam subyek. Obyek berada dalam realitasnya. Aktifitas subyek (penelitian) terdiri dari mengingat (remembering); mencerap/mengerti (perceiving) dan menghendaki (desiring), ketiganya mengarah (directedness) kepada pengalaman/ peristiwa; pengetahuan tentang "sesuatu" atau keindahan dan kebaikan. Inilah yang disebut dengan intensionalitas. Jadi fenomenologi adalah ilmu atau metodologi tentang pencarian meaning/makna. 
Berbeda dengan mode pemikiran filsafat barat pada umumnya yang bersifat logis-formalis di satu sisi dan bersifat empiris-positivis pada sisi yang lain, pemikiran Husserl lebih bersifat intuitif gagasan intuitif. Gagasan intensionalitas membuat manusia dan realitas benar-benar membentuk suatu jalinan sejarah, dalam arti "beruang" dan berwaktu". Dengan "beruang" dan "berwaktu" dunia akan menjadi penuh makna. Adanya bukan hanya masuk dalam bilangan tetapi dalam hitungan. Inilah makna eksistensialisme.

\section{DAFTAR PUSTAKA}

Abbas Hamimi Mintaredja. (1983) .Teori Pengetahuan Menurut Berger. Laporan Penelitian Fakultas Filsafat UGM. Yogyakata: UGM,

Craib, Ian. (1992) Teori-teori Sosial Modern: Dari Parsons Sampai Habermas, Rajawali Pers, Jakarta.

Campbell, Tom. (1994) Tujuh Teori Sosial, terjemahan F. Budi Hardiman. Yogyakarta: Kanisius.

Connolly, Peter. (2002) Aneka Pendekatan Studi Agama. Yogyakarta: LKiS.
Gallagher, T. Kenneth. (1984) Epistemologi, sadur oleh Hardono Hadi, Yogyakarta: Kanisius, 1984

Harun Hadiwijono. (1980) Sari Sejarah Filsafat Barat 2. Yogyakarta: Kanisius.

Http://FenomenologiTeori\%20«\%20Teguh\%20Iman \%20Prasetya.mht

http://plato.stanford.edu/entries/phenomenology/, diakses tanggal 05 Mei 2009.

Mayol, Velarde, Viktor. On Herrserl. USA: Belmont, $\mathrm{tt}$.

Muslih, Mohammad, (2204) Filsafat Ilmu Yogyakarta: Belukar.

Ritzer, George. (1983) Contenporary Sociological Theory, New York: Alfred A. Knopt

Schultz, Alfred. (1967) The Phenomenology of the Social World, Northwertern, USA.

Shofiyullah Mz. (Juli 2002) Fenomenologi Edmund Husserl (Suatu Pendekatan Memahami Ketegangan Religiusitas). Jurnal Ilmu-ilmu Ushuluddin Esensia. 13(2).

Zubaidi, Sujiat, dan Muslih Mohammad. (213) Kritik Epistemologi dan Model Pembacaan Kontemporer, Yogyakarta: LESFI. 